TITLE:

\title{
Efficacy and safety of granulocyte and monocyte adsorption apheresis for ulcerative colitis: A meta-analysis.
}

\section{$\operatorname{AUTHOR}(\mathrm{S})$ :}

Yoshino, Takuya; Nakase, Hiroshi; Minami, Naoki; Yamada, Satoshi; Matsuura, Minoru; Yazumi, Shujiro; Chiba, Tsutomu

\section{CITATION:}

Yoshino, Takuya ...[et al]. Efficacy and safety of granulocyte and monocyte adsorption apheresis for ulcerative colitis: A meta-analysis.. Digestive and liver disease : official journal of the Italian Society of Gastroenterology and the Italian Association for the Study of the Liver 2014, 46(3): 219-226

\section{ISSUE DATE:}

2014-03

URL:

http://hdl.handle.net/2433/182932

\section{RIGHT:}

(C) 2013 Editrice Gastroenterologica Italiana S.r.l. Published by Elsevier Ltd.; This is not the published version. Please cite only the published version.; この論文は出版社版でありません。引用の際には出版社版を ご確認ご利用ください。 


\section{Efficacy and Safety of Granulocytes and Monocytes Adsorption Apheresis for}

\section{Ulcerative Colitis}

\section{-A Meta-Analysis Study-}

Takuya Yoshino, $\mathrm{MD}, \mathrm{PhD}^{1,2}$, Hiroshi Nakase, $\mathrm{MD}, \mathrm{PhD}^{1}$, Naoki Minami, $\mathrm{MD}^{1}$, Satoshi Yamada, MD ${ }^{1}$, Minoru Matsuura, MD, $\mathrm{PhD}^{1}$, Shujiro Yazumi, MD, $\mathrm{PhD}^{2}$, Tsutomu Chiba, MD, $\mathrm{PhD}^{1}$

1. Department of Gastroenterology \& Hepatology, Graduate School of Medicine, Kyoto University

2. Division of Gastroenterology \& Hepatology, Digestive Disease Center, Kitano Hospital

Correspondence to Hiroshi Nakase, MD, PhD

Department of Gastroenterology \& Hepatology, Graduate School of Medicine, Kyoto University, 54 Kawahara-cho, Shogoin, Sakyo-ku, Kyoto, 606-8507, Japan

Phone: $+81-75-751-4319$

Fax: $+81-75-751-4303$ 
Acknowledgement: This work was supported by Japan Society for the Promotion of Science “KAKENHI” Grant Number 25130706, 24229005, 24659363, 24590941, 25860532 and 24590941 by Health and Labour Sciences Research Grants for Research on Rare and Intractable Disease from the Ministry of Health, Labour and Welfare, Japan. 


\section{Abstract}

Background and aim: Safe and effective treatments are required for patients with ulcerative colitis. It was suggested that granulocytes and monocytes adsorption apheresis could play an important role in treatment for ulcerative colitis. Therefore, a meta-analysis was performed to investigate the usefulness of granulocytes and monocytes adsorption apheresis for ulcerative colitis.

Methods: Medline and the Cochrane controlled-trials register were used to identify randomized controlled-trials comparing granulocytes and monocytes adsorption apheresis with corticosteroids, intensive with conventional apheresis in patients with ulcerative colitis.

Results: Nine randomized-trials were eligible for inclusion criteria. According to pooled data, granulocytes and monocytes adsorption apheresis is effective for inducing clinical remission in patients with ulcerative colitis compared with corticosteroids (odds ratio, $2.23 ; 95 \%$ confidence interval: $1.38-3.60)$. However, the efficacy of granulocytes and monocytes adsorption apheresis was not dependent on the number of apheresis-sessions. The intensive-apheresis ( $\geq 2$ sessions per week) is more effective for inducing clinical remission than weekly-apheresis (odds ratio, 2.10; 95\% confidence interval: 1.12-3.93). The rate of adverse events by apheresis was significantly lower than that by 
corticosteroids (odds ratio, $0.24 ; 95 \%$ confidence interval: $0.15-0.37$ ).

Conclusion: Our meta-analysis reveals that intensive granulocytes and monocytes adsorption apheresis is a safe and effective treatment with higher rates of clinical remission and response for ulcerative colitis compared with corticosteroids.

Key Words: granulocytes and monocytes adsorption apheresis, ulcerative colitis, corticosteroids

The number of words: 3728 words 


\section{Introduction:}

Ulcerative colitis (UC) is a chronic relapsing gastrointestinal disorder characterized by inflammation of the colonic mucosa [1]. 5-aminosalicylates (5-ASA) and corticosteroids are conventionally used as treatment for UC. 5-ASA, such as mesalazine, is used as initial induction and maintenance therapy for clinical remission in UC patients [2-4]. In patients with UC refractory to 5-ASA, administration of corticosteroids is considered the next main strategy for induction therapy [5, 6]. Recent evidence indicates that calcineurin inhibitors and anti-tumor necrosis factor (TNF)- $\alpha$ agents are effective treatments for patients with UC refractory to corticosteroids [7-10]. These immunosuppressive therapies, however, are associated with several adverse events, such as opportunistic infection, infusion reaction and bone marrow suppression $[11,12]$. Moreover, resent reports suggest that the combination therapy with immunomodulators and anti TNF- $\alpha$ agents is associated with an increased risk of malignancy, such as malignant lymphoma $[13,14]$. Therefore, less hazardous and safer long-term treatments are needed for maintenance of clinical remission in patients with UC.

The pathophysiology of UC remains unclear. UC is associated with an increase in circulating leukocytes and immune complexes $[15,16]$. Neutrophil granulocytes and 
monocytes/macrophages produce proinflammatory cytokines such as TNF- $\alpha$ and interferon (IFN)- $\gamma$, and these proinflammatory cytokines contribute to intestinal inflammation in UC $[17,18]$. The level of fecal calprotectin, a member of the $\mathrm{Ca}^{2+}$-binding S100 family of proteins that is expressed in the cytoplasm of activated neutrophils and has proinflammatory properties, is related to the severity of UC [19], suggesting that removal of circulating neutrophil granulocytes is a theoretically rational treatment for UC.

Granulocyte and monocyte adsorption apheresis (GMAA) using Adacolumn ${ }^{\circledR}$ (JIMRO, Takasaki, Gunma, Japan) to remove activated neutrophil granulocytes is thus a promising therapeutic option for patients with UC [20, 21]. The column is filled with cellulose acetate beads (leukocyte apheresis carriers) of $2 \mathrm{~mm}$ in diameter that are bathed in sterile saline. These leukocyte apheresis carriers selectively adsorb granulocytes and monocytes/macrophages that bear Fc $\gamma$ and complement receptors. Several clinical trials have reported the efficacy of GMAA for treatment of UC $[22,23]$. Moreover, intensive apheresis with more than two sessions per week induces rapid clinical remission in patients with active UC compared with weekly GMAA (1 session per week) [24]. It remains unclear, however, whether GMAA is not inferior to corticosteroids for inducing the remission of UC because numerous clinical trials 
reported no significant difference between GMAA and conventional treatment with corticosteroids.

The aim of the study was to investigate the usefulness of GMAA for patients with active UC compared with corticosteroids. Moreover, we also evaluate GMAA regimens that are useful for the treatment of UC as sub-analysis. 


\section{Materials and Methods:}

Search Strategy: A search of the medical literature was conducted using MEDLINE, the Cochrane controlled trials register (up to January 2012) and the abstract books of recent international congress, such as Digestive Disease Week 2012, 2013, and $8^{\text {th }}$ Congress of European Crohn's and Colitis Organization, to identify comparative studies of GMAA in patients with UC. The search terms "apheresis" and "adsorption" were used in combination with "inflammatory bowel disease" and "ulcerative colitis". All abstracts were retrieved from the database according to this strategy.

Inclusion criteria: Only randomized control trials were included. The populations of these studies comprised patients with active UC. Studies included at least two branches: a conventional group treated with corticosteroids and a GMAA group. Moreover, studies comparing GMAA regimens were included for subanalysis; for example, more than 10 GMAA-sessions vs. 5 GMAA-sessions, and intensive GMAA-regimens $(\geq 2$ sessions per week) vs. weekly GMAA-regimens (1 session per week). Papers were included if they provided information on at least one of the following outcome parameters: clinical response rate, clinical remission rate, clinical disease activity index, steroid-sparing effect, endoscopic findings, histological findings, number of adverse events, and withdrawals. 
Data extraction: Data were extracted independently by two reviewers, including author, year, location of trial, trial design, population of studies, number of enrolled subjects, variety of GMAA preparations, dose of administration, and study quality.

Assessment of bias: Risk of bias was assessed independently by two investigators as described in the Cochrane handbook by recording the method used to generate the randomization schedule, the method used to conceal allocation, whether blinding was implemented, the proportion of patients that completed follow-up, whether an intention-to treat analysis was extractable, and whether there was evidence of selective reporting of outcomes.

Statistical analysis: A meta-analysis was performed with Review Manager 5.1 (Cochrane Collaboration, Oxford, CA). The outcome measure examined was the odds ratios (ORs) of the clinical remission rate or clinical response rate and the ratio of adverse events with GMAA vs. corticosteroids by intention-to-treat analysis. Moreover, the outcome measure also examined the ORs of the clinical remission rate with more than 10 GMAA-sessions vs. 5 sessions, and intensive GMAA vs. weekly GMAA. The heterogeneity of these studies was assessed using the chi-square test. Forest plots were created for graphic display of the results. The size of a box indicates the relative weight of the respective study, while the line gives the $95 \%$ confidence interval (95\% CI). For 
Yoshino et al.

the meta-analysis result, the diamond represents the $95 \% \mathrm{CI}$. 


\section{Results:}

Description of studies: The search strategy identified a total of 400 citations (Figure 1). 383 of 400 citations were excluded (Review: 97, Case Reports: 79, Letter and Editorial: 48, Basic Research: 53, and other medical topics: 106). Seventeen of those articles were retrieved and evaluated in more detail. Of 17 studies, 9 were included. The characteristics of these 9 studies were summarized in Table 1. Of these 9,4 studies compared GMAA with corticosteroids [22, 24-26], one study was sham-controlled double-blinded randomized trial [27], 2 studies compared more than 10 GMAA-sessions vs. 5 GMAA-sessions [28, 29], and the remaining 2 studies compared an intensive GMAA-regimen ( $\geq 2$ sessions per week) vs. a weekly GMAA-regimen (1 session per week) [30, 31]. Moreover, 4 studies compared the rate of adverse events between GMAA and corticosteroids [22, 24, 26, 27]. Of the 17 studies, 8 were excluded, because 3 made no comparison with GMAA, one paper alone compared daily GMAA with intensive GMAA, 2 were not randomized studies, and whether or not the same patients were included in other studies were unclear in the remaining 2.

Efficacy of GMAA compared with corticosteroids on clinical remission rate in patients with active UC: Three studies were evaluated for the efficacy of GMAA compared with corticosteroids on clinical remission rate in patients with active UC [22, 
$24,26]$. One study was sham-controlled double-blinded randomized trial and evaluated for the efficacy of GMAA compared with conventional therapy including corticosteroids on clinical remission rate in patients with active UC [27]. There was heterogeneity of study characteristics, such as characteristics of enrolled patients, criteria used to define clinical remission and treatment protocol. Of 4 studies, 3 were including patients with moderately to severely active UC [22, 24, 27]. However, the study of Bresci, et al. was including patients with mildly active UC [26]. The studies by Bresci et al. and Sands et al. were used clinical activity score and Mayo score, respectively $[26,27]$. On the other hand, original scoring based on clinical symptoms, endoscopic findings and inflammatory markers was used to define clinical remission in the remaining two studies [22, 24]. Moreover, 2 of 4 studies compared 5 weekly GMAA-sessions with that of corticosteroids $[22,32]$. One study compared an intensive GMAA-regimen (2 sessions per week) with that of corticosteroids [24] and the remaining one study compared 10 weekly GMAA-sessions with 10 weekly sham-sessions [27]. All of those studies reported that the rate of clinical remission in patients treated with GMAA was high compared with that in patients treated with corticosteroids, although the difference was not statistically significant in two of four studies. The pooled clinical remission rate of GMAA was 33.2\% (90/271 patients), 
whereas that of corticosteroids was $25.1 \%$ (50/199 patients; Figure 2A). The OR was 2.23 (95\%CI 1.38-3.60; $P<0.001)$. Thus, GMAA would be effective for induction of clinical remission in patients with active UC compared with corticosteroids.

Efficacy of GMAA compared with corticosteroids on the clinical response rate in

patients with active UC: Five studies were identified and evaluated for efficacy of GMAA on the clinical response rate compared with corticosteroids in patients with active UC. There was heterogeneity of study characteristics, such as characteristics of enrolled patients, criteria used to define clinical response and treatment protocol. Of 5 studies, 3 studies were including patients with moderately to severely active UC [22, 24, 27]. However, the study by Nakamura, et al. was including patients with moderately active UC [25], and the study by Bresci, et al. was including patients with mildly active UC [26]. In two of 5 studies, clinical activity index scoring was used to define clinical response [24, 26]. Moreover, 3 of 5 studies compared 5 weekly GMAA-sessions with that of corticosteroids $[22,25,26]$. One study compared an intensive GMAA-regimen (2 sessions per week) with that of corticosteroids [24] and the remaining one study compared 10 weekly GMAA-sessions with 10 weekly sham-sessions [27]. All five studies reported that the rate of clinical response, including clinical improvement and remission, in patients treated with GMAA tended to be higher than that in patients 
treated with corticosteroids, although the difference was not statistically significant, except for in Nakamura's report (GMAA 80\%; Control 20\%; $P<0.05$ ) [25] and Bresci's paper (GMAA 92.5\%; Control 65\%; $P<0.05$; Figure 2B) [26]. The pooled response rate was higher in the GMAA group than in the corticosteroids group (169/281 [60.1\%] vs. $102 / 209$ [48.8\%]). The OR was 1.94 (95\%CI 1.32-2.85; $P<0.001)$. These data indicated that GMAA was effective for inducing a clinical response in patients with active UC, compared with corticosteroids.

Efficacy of GMAA compared with corticosteroids in patients with severe and moderate active UC: We evaluated the efficacy of GMAA in patients with severely and moderately active UC, respectively, because the difference of disease activity of enrolled patients might contribute to heterogeneity for data analysis. Shimoyama, et al. reported that 5 of 19 patients $(26.3 \%)$ with severe UC achieved clinical remission five weeks after treatment with GMAA, although only one of 19 patients (5.3\%) achieved it after treatment with corticosteroids [22]. Sands, et al. also reported that, in patients with severe activity UC, a significant difference of remission and response rate was observed between GMAA group (24\% and 54\%, respectively) and sham group (0\% and $18 \%$, respectively) ( $P=0.03$ and 0.01 for clinical remission and clinical response, respectively) [27]. Therefore, meta-analysis, using Shimoyama's trial, Hanai's trial and Sands' trial 
that included severe UC patients, revealed that the pooled clinical remission rate of GMAA was $42.0 \%$ (42 of 100 patients), whereas that of corticosteroids was $23.9 \%$ (17 of 71 patients; Figure 3A) [22, 24, 27]. The OR was 4.64 (95\%CI 1.95-11.04; $P<0.001)$. Four of five trials that evaluated the effect of GMAA compared with that of corticosteroids included patients with moderate UC. However, in Sands' paper, the number of patients with moderate UC was not mentioned [27]. Therefore, meta-analysis, using Shimoyama's trial, Nakamura's trial and Bresci's trial that mentioned the number of moderately active UC-patients, revealed that the pooled clinical remission rate of GMAA was $51.1 \%$ (43 of 84 patients), whereas that of corticosteroids was $31.3 \%$ (26 of 83 patients; Figure 3B) [22, 25, 26]. The OR was $2.82(95 \%$ CI $1.39-5.73 ; P<0.05)$. Therefore, GMAA would not be inferior to corticosteroids for induction of clinical remission in UC patients with not only moderately but also severely active UC.

\section{The clinical remission rate in UC patients treated with 10 GMAA-sessions}

compared that with 5 GMAA-sessions: Two studies reported the efficacy of 10 GMAA-sessions on the clinical remission rate compared with 5 GMAA-sessions in patients with active UC $[28,29]$. However, the heterogeneity of study characteristics, such as characteristics of enrolled patients and treatment protocol was observed as follows; Ricart's trial included patients with moderately active UC [28]. Dignass's trial 
included patients with not only moderately but also severely active UC [29]. Ricart's trial compared 10 weekly GMAA-sessions with 5 weekly GMAA-sessions, whereas Dignass's trial compared intensive GMAA, such as 2 apheresis per week over 2 weeks followed by 6 apheresis over 6 weeks, with 5 weekly GMAA-sessions. Based on the pooled data, the clinical remission rate of patients treated with 10 GMAA-sessions tended to be higher than that of patients treated with 5 GMAA-sessions upon the completion of GMAA treatment (41 of 93 patients $(44.1 \%$ ) vs. 35 of 88 patients (39.8\%); Figure 4A). However, the OR was 1.19 (95\% CI 0.66-2.16; $P=0.56$ ), and there was no significant difference in the clinical remission rate between 10 GMAA-sessions and 5 GMAA-sessions. The efficacy of GMAA was not dependent on the number of GMAA-sessions.

\section{The clinical remission rate in UC patients treated with intensive GMAA compared}

with weekly GMAA: Three studies reported the efficacy of intensive GMAA (2 or 3 sessions per week) on the clinical remission rate compared with weekly GMAA (1 session per week) [29-31]. Dignass's trial included patients with not only moderately but also severely active UC [29]. On the other hand, the trial by Sakuraba et al. at 2008 was included patients with moderately active UC [30], and the other trial at 2009 was included those with mild to moderately active UC [31]. On the basis of taking into 
consideration of the heterogeneity of enrolled patients and protocol, thus, the pooled data indicated that the clinical remission rate of patients treated with intensive GMAA was higher than that of patients treated with weekly GMAA (100 of 170 patients (58.8\%) vs. 83 of 171 patients (48.5\%); Figure 4B). The OR was 1.57 (95\% CI 1.01-2.44; $P=0.05)$. Therefore, these data suggested that an intensive GMAA-regimen is suitable for achieving clinical remission in patients with active UC.

Adverse events: The rate of adverse events was reported in four studies [22, 24, 26, 27]. According to those studies, frequent adverse events in the GMAA group were headache and flushing. Sands' trial reported the high rate of adverse events during treatment [27]. Moreover, that trial alone reported serious adverse events in which the most common serious adverse event was exacerbation of UC in two of apheresis-treated patients and four of sham-treated patients, respectively. There were no patients that discontinued the clinical trial due to adverse events related to GMAA. There was no evidence of opportunistic infection in the GMAA group. Based on the pooled data, 145 of 277 (52.3\%) patients treated with GMAA experienced an adverse event (Figure 5). On the other hand, 137 of $203(67.5 \%)$ patients treated with corticosteroids experienced an adverse event. The OR was 0.21 (95\%CI $0.13-0.35 ; P<0.001)$. Therefore, the rate of adverse events related to GMAA was significantly lower than that related to 
Yoshino et al.

corticosteroids. 


\section{Discussion:}

Our meta-analysis revealed that the efficacy of GMAA is not inferior to that of corticosteroids in the rate of clinical remission and response of patients with active UC. This study also revealed that GMAA is safer for patients with active UC than corticosteroids.

A number of previous studies, including randomized, non-randomized, and case studies, reported that the rate of clinical remission and response in refractory UC patients treated with GMAA was higher than that in patients treated with corticosteroids[23, 33]. On the other hand, Sands, et al. reported that there was no significant difference of remission rate between UC patients treated with GMAA and those with sham treatment [27]. The reason of discrepancy between the report by Sands, et al. and the others might be related to the characteristics of enrolled patients, such as their disease activity and co-medications. Particularly, the possibility that the efficacy of GMAA treatment depends on how severe UC-activity is must be considered, because the heterogeneity of UC severity might affect data analysis. Yamamoto, et al. reported the effect of GMAA on patients with severe UC [34]. In that study, none of the patients with severe UC achieved clinical remission after treatment with GMAA. Nevertheless the negative trial by Sands, et al. was included in this study, however, our meta-analysis 
revealed that the rate of clinical remission in UC patients treated with GMAA was significantly higher than that of corticosteroid. Therefore, these data indicate that treatment with GMAA is optimal for active UC patients.

The GMAA regimen that would be most effective for treatment of UC has not yet been established, although several studies have evaluated the therapeutic effects of GMAA by comparing GMAA regimens [28-30]. Therefore, to determine the most useful GMAA regimen for UC in detail, we evaluated the effect of each GMAA regimen by performing a meta-analysis, comparing 10 GMAA-sessions vs. 5 GMAA-sessions, and intensive GMAA vs. weekly GMAA. Ricart, et al. reported that the clinical remission rate in UC patients treated with 10 GMAA-sessions was higher than that in patients treated with 5 GMAA-sessions [28], while Dignass, et al. reported that the efficacy of 5 GMAA-sessions was not inferior to that of 10 GMAA-sessions [29]. Our meta-analysis revealed that there was no significant difference in the clinical remission rate between 10 GMAA-sessions and 5 GMAA-sessions, despite the difference in the duration of treatment between groups. Therefore, the efficacy of GMAA was not dependent on the number of GMAA-sessions, although two studies showed a trend toward superiority of treatment with 10 GMAA-sessions.

We compared the efficacy of intensive GMAA ( $\geq 2$ sessions per week) with that of 
weekly GMAA. Sakuraba, et al. reported that intensive GMAA was significantly superior to weekly GMAA with regard to the clinical remission rate [30, 31]. Moreover, the mean time to achieve clinical remission in the intensive GMAA group was significantly shorter than that in the weekly GMAA group. Our meta-analysis also revealed that the efficacy of intensive GMAA was higher than that of weekly GMAA. Based on these data, intensive GMAA is suitable for the induction of clinical remission in patients with active UC.

Achieving mucosal healing is currently focused on the possibility of affecting the long-term clinical outcome of UC, because mucosal healing is associated with reduced rates of hospitalization and colectomy [35]. Therefore, achieving mucosal healing is an important therapeutic goal for patients with inflammatory bowel disease. However, there were a few reports about the association between treatment with GMAA and mucosal healing [36, 37]. Fukuchi, et al. reported the efficacy of intensive GMAA for achieving mucosal healing in UC patients without concomitant corticosteroids compared with weekly GMAA [37]. Moreover, the cumulative non-relapse ratio of UC patients treated with intensive GMAA was significantly higher than that of patients treated with weekly GMAA. These data first demonstrated that intensive GMAA would be favorable to weekly GMAA for achieving mucosal healing, although further studies 
are required to determine the effect of intensive GMAA for achieving mucosal healing in patients with active UC.

Approximately $10 \%$ of UC patients present with severe disease, and the remaining $90 \%$ present with mild to moderate disease activity [38, 39]. These epidemiologic evaluations indicate the importance of controlling mild- to moderately-active UC by highly therapeutic and safe treatments. Several immunosuppressive therapies, such as immunomodulators and anti TNF- $\alpha$ agents, have been used for patients with refractory UC $[8,9,11]$. The therapeutic strategy for refractory UC remains challenging, however, because the use of these immunosuppressive agents is associated with an increased risk of adverse events. Considering that GMAA is a natural biologic treatment for inflammatory bowel disease [20, 21], GMAA might be a safer alternative to immunosuppressive therapies. Our findings indicate that GMAA is associated with a low frequency of adverse events in comparison with corticosteroids. The fact that none of the patients in previous clinical trials discontinued GMAA treatment due to adverse events strongly supports the safety of GMAA [22, 24, 26, 27, 40]. In addition to fewer side effects of GMAA, there is one possible reason why GMAA is recommended for active UC patients prior to corticosteroid. In general, corticosteroid can down-regulate the expression of $\mathrm{Fc} \gamma$ and complement receptors of granulocytes and 
monocytes/macrophages with which GMAA carriers selectively bind [41]. In this regard, administration of corticosteroid prior to GMAA might affect the therapeutic efficacy of GMAA. In fact, the ratio of clinical remission and response was higher in steroid-naïve UC patients treated with GMAA than in steroid-refractory patients [42]. Taken together, we considered that treatment with GMAA plays an important role in the management of mildly- to moderately-active UC.

One limitation of this study concerns the difference of disease activity of patients and co-treatments at enrolled, which might contribute to heterogeneity for data analysis. Moreover, it may be argued that the biases of performance (blinding of participants and personnel) and detection (blinding of outcome assessment) might be high, because most of all studies were open-labeled randomized studies due to the characteristic of GMAA. Thus, postulating heterogeneity of patient's characteristics, our meta-analysis data might be deliberately interpreted.

In conclusion, our meta-analysis reveals that GMAA is a useful and safe treatment for patients with active UC. Further studies are needed to determine accurately when and how to use GMAA as a therapeutic option for UC. 


\section{References:}

[1] Hanauer SB. Inflammatory bowel disease: epidemiology, pathogenesis, and therapeutic opportunities. Inflamm Bowel Dis. 2006;12 Suppl 1:S3-9.

[2] Williams CN, Haber G, Aquino JA. Double-blind, placebo-controlled evaluation of 5-ASA suppositories in active distal proctitis and measurement of extent of spread using 99mTc-labeled 5-ASA suppositories. Dig Dis Sci. 1987;32:71S-5S.

[3] Sutherland LR, Martin F, Bailey RJ, et al. A randomized, placebo-controlled, double-blind trial of mesalamine in the maintenance of remission of Crohn's disease. The Canadian Mesalamine for Remission of Crohn's Disease Study Group. Gastroenterology. 1997;112:1069-77.

[4] Hanauer S, Schwartz J, Robinson M, et al. Mesalamine capsules for treatment of active ulcerative colitis: results of a controlled trial. Pentasa Study Group. Am J Gastroenterol. 1993;88:1188-97.

[5] Truelove SC, Witts LJ. Cortisone in ulcerative colitis; final report on a therapeutic trial. Br Med J. 1955;2:1041-8.

[6] Baron JH, Connell AM, Kanaghinis TG, et al. Out-patient treatment of ulcerative colitis. Comparison between three doses of oral prednisone. Br Med J. 1962;2:441-3.

[7] Rutgeerts P, Sandborn WJ, Feagan BG, et al. Infliximab for induction and 
maintenance therapy for ulcerative colitis. N Engl J Med. 2005;353:2462-76.

[8] Yamamoto S, Nakase H, Mikami S, et al. Long-term effect of tacrolimus therapy in patients with refractory ulcerative colitis. Aliment Pharmacol Ther. 2008;28:589-97.

[9] Yamamoto S, Nakase H, Matsuura M, et al. Efficacy and safety of infliximab as rescue therapy for ulcerative colitis refractory to tacrolimus. J Gastroenterol Hepatol. 2010;25:886-91.

[10] Sandborn WJ. Cyclosporine therapy for inflammatory bowel disease: definitive answers and remaining questions. Gastroenterology. 1995;109:1001-3.

[11] Sandborn WJ, Rutgeerts P, Feagan BG, et al. Colectomy rate comparison after treatment of ulcerative colitis with placebo or infliximab. Gastroenterology. 2009;137:1250-60; quiz 520.

[12] Talar-Williams C, Sneller MC. Complications of corticosteroid therapy. Eur Arch Otorhinolaryngol. 1994;251:131-6.

[13] Mackey AC, Green L, Liang LC, et al. Hepatosplenic T cell lymphoma associated with infliximab use in young patients treated for inflammatory bowel disease. J Pediatr Gastroenterol Nutr. 2007;44:265-7.

[14] Herrinton LJ, Liu L, Weng X, et al. Role of thiopurine and anti-TNF therapy in lymphoma in inflammatory bowel disease. Am J Gastroenterol. 2011;106:2146-53. 
[15] Fiocchi C. Inflammatory bowel disease: etiology and pathogenesis.

Gastroenterology. 1998;115:182-205.

[16] Xavier RJ, Podolsky DK. Unravelling the pathogenesis of inflammatory bowel disease. Nature. 2007;448:427-34.

[17] Papadakis KA, Targan SR. Role of cytokines in the pathogenesis of inflammatory bowel disease. Annu Rev Med. 2000;51:289-98.

[18] Schreiber S, Nikolaus S, Hampe J, et al. Tumour necrosis factor alpha and interleukin 1beta in relapse of Crohn's disease. Lancet. 1999;353:459-61.

[19] Tibble JA, Sigthorsson G, Bridger S, et al. Surrogate markers of intestinal inflammation are predictive of relapse in patients with inflammatory bowel disease. Gastroenterology. 2000;119:15-22.

[20] Saniabadi AR, Hanai H, Takeuchi K, et al. Adacolumn, an adsorptive carrier based granulocyte and monocyte apheresis device for the treatment of inflammatory and refractory diseases associated with leukocytes. Ther Apher Dial. 2003;7:48-59.

[21] Hiraishi K, Takeda Y, Shiobara N, et al. Studies on the mechanisms of leukocyte adhesion to cellulose acetate beads: an in vitro model to assess the efficacy of cellulose acetate carrier-based granulocyte and monocyte adsorptive apheresis. Ther Apher Dial. 2003;7:334-40. 
[22] Shimoyama T, Sawada K, Hiwatashi N, et al. Safety and efficacy of granulocyte and monocyte adsorption apheresis in patients with active ulcerative colitis: a multicenter study. J Clin Apher. 2001;16:1-9.

[23] Hanai H, Watanabe F, Yamada M, et al. Adsorptive granulocyte and monocyte apheresis versus prednisolone in patients with corticosteroid-dependent moderately severe ulcerative colitis. Digestion. 2004;70:36-44.

[24] Hanai H, Iida T, Takeuchi K, et al. Intensive granulocyte and monocyte adsorption versus intravenous prednisolone in patients with severe ulcerative colitis: an unblinded randomised multi-centre controlled study. Dig Liver Dis. 2008;40:433-40.

[25] Nakamura T, Kawagoe Y, Matsuda T, et al. Effect of granulocyte and monocyte adsorption apheresis on urinary albumin excretion and plasma endothelin-1 concentration in patients with active ulcerative colitis. Blood Purif. 2004;22:499-504.

[26] Bresci G, Parisi G, Mazzoni A, et al. Granulocytapheresis versus methylprednisolone in patients with acute ulcerative colitis: 12-month follow up. J Gastroenterol Hepatol. 2008;23:1678-82.

[27] Sands BE, Sandborn WJ, Feagan B, et al. A randomized, double-blind, sham-controlled study of granulocyte/monocyte apheresis for active ulcerative colitis. Gastroenterology. 2008;135:400-9. 
[28] Ricart E, Esteve M, Andreu M, et al. Evaluation of 5 versus 10 granulocyteaphaeresis sessions in steroid-dependent ulcerative colitis: a pilot, prospective, multicenter, randomized study. World J Gastroenterol. 2007;13:2193-7.

[29] Dignass AU, Eriksson A, Kilander A, et al. Clinical trial: five or ten cycles of granulocyte-monocyte apheresis show equivalent efficacy and safety in ulcerative colitis. Aliment Pharmacol Ther. 2010;31:1286-95.

[30] Sakuraba A, Sato T, Naganuma M, et al. A pilot open-labeled prospective randomized study between weekly and intensive treatment of granulocyte and monocyte adsorption apheresis for active ulcerative colitis. J Gastroenterol. 2008;43:51-6.

[31] Sakuraba A, Motoya S, Watanabe K, et al. An open-label prospective randomized multicenter study shows very rapid remission of ulcerative colitis by intensive granulocyte and monocyte adsorptive apheresis as compared with routine weekly treatment. Am J Gastroenterol. 2009;104:2990-5.

[32] Bresci G, Parisi G, Capria A. Duration of remission and long-term prognosis according to the extent of disease in patients with ulcerative colitis on continuous mesalamine treatment. Colorectal Dis. 2008;10:814-7.

[33] Yoshino $T$, Nakase $H$, Matsuura $M$, et al. Effect and safety of granulocyte-monocyte adsorption apheresis for patients with ulcerative colitis positive 
for cytomegalovirus in comparison with immunosuppressants. Digestion. 2011;84:3-9.

[34] Yamamoto T, Umegae S, Matsumoto K. Daily granulocyte and monocyte adsorptive apheresis in patients with active ulcerative colitis: a prospective safety and feasibility study. J Gastroenterol. 2011;46:1003-9.

[35] Colombel JF, Rutgeerts P, Reinisch W, et al. Early mucosal healing with infliximab is associated with improved long-term clinical outcomes in ulcerative colitis. Gastroenterology. 2011;141:1194-201.

[36] Yamamoto T, Umegae S, Matsumoto K. Mucosal healing in patients with ulcerative colitis during a course of selective leukocytapheresis therapy: a prospective cohort study. Inflamm Bowel Dis. 2010;16:1905-11.

[37] Fukuchi T, Nakase H, Ito D, et al. Rapid induction of mucosal healing by intensive granulocyte and monocyte adsorptive aphaeresis in active ulcerative colitis patients without concomitant corticosteroid therapy. Aliment Pharmacol Ther. 2011;34:583-5.

[38] Sinclair TS, Brunt PW, Mowat NA. Nonspecific proctocolitis in northeastern Scotland: a community study. Gastroenterology. 1983;85:1-11.

[39] Stonnington CM, Phillips SF, Zinsmeister AR, Melton LJ, 3rd. Prognosis of chronic ulcerative colitis in a community. Gut. 1987;28:1261-6.

[40] Bresci G, Parisi G, Mazzoni A, et al. Treatment of patients with acute ulcerative 
colitis: conventional corticosteroid therapy (MP) versus granulocytapheresis (GMA): a pilot study. Dig Liver Dis. 2007;39:430-4.

[41] Hepburn AL, Mason JC, Davies KA. Expression of Fcgamma and complement receptors on peripheral blood monocytes in systemic lupus erythematosus and rheumatoid arthritis. Rheumatology (Oxford). 2004;43:547-54.

[42] Hanai H, Watanabe F, Takeuchi K, et al. Leukocyte adsorptive apheresis for the treatment of active ulcerative colitis: a prospective, uncontrolled, pilot study. Clin Gastroenterol Hepatol. 2003;1:28-35. 


\section{Table 1: Characteristics of included studies in this meta-analysis}

${ }^{1}$ Original clinical activity score: Original scoring system composed of three factors as follows; abdominal symptoms (abdominal pain, bloody stool and diarrhea), endoscopic findings of active UC (erosions, ulcers, mucous and bloody stool and indistinct vascular pattern) and change of serum level of C-reactive protein. Clinical remission was defined in case of patients having all three factors, such as absence of abdominal symptoms, improvement of endoscopic findings and normalization or significant reduction of serum level of C-reactive protein. Clinical response was defined in case of those having two of all factors.

${ }^{2} \mathrm{CAI}$ score: clinical activity index score

${ }^{3} 20$ patients with moderate UC: 20 patients with corticosteroid-dependent moderate UC were enrolled in Ricart's trial. The range of clinical activity index score was 6 to 12 .

${ }^{4} 186$ patients with moderate-severe UC: 186 patients with corticosteroid-dependent or -resistant moderate-severe UC were enrolled in Dignass's trial. The mean clinical activity index score was 8.8 . 


\section{Figure Legend:}

Figure 1: Literature screening and selection process.

The search strategy identified a total of 400 citations. 383 of 400 citations were excluded and the remaining seventeen were retrieved and evaluated in more detail. Of 17 studies, 9 were included in this meta-analysis.

GMAA; granulocytes and monocytes adsorption apheresis

Figure 2: The effect of granulocytes and monocytes adsorption apheresis compared with corticosteroids on rate of clinical remission and response in patients with active ulcerative colitis.

(A) The effect of granulocytes and monocytes adsorption apheresis compared with corticosteroids on clinical remission rate in patients with active ulcerative colitis.

(B) The effect of granulocytes and monocytes adsorption apheresis compared with corticosteroids on clinical response rate in patients with active ulcerative colitis.

GMAA; granulocytes and monocytes adsorption apheresis

M-H; Mantel-Haenszel

CI; confidence interval 
Figure 3: The effect of granulocytes and monocytes adsorption apheresis compared with corticosteroids on clinical remission rate in patients with severe and moderate ulcerative colitis.

(A) The effect of granulocytes and monocytes adsorption apheresis compared with corticosteroids on clinical remission rate in patients with severe ulcerative colitis.

(B) The effect of granulocytes and monocytes adsorption apheresis compared with corticosteroids on clinical remission rate in patients with moderate ulcerative colitis.

GMAA; granulocytes and monocytes adsorption apheresis

\section{M-H; Mantel-Haenszel}

CI; confidence interval

Figure 4: The evaluation of therapeutic effect of granulocytes and monocytes adsorption apheresis on clinical remission rate in patients with active ulcerative colitis by comparing granulocytes and monocytes adsorption apheresis regimens.

(A) The effect of 10 granulocytes and monocytes adsorption apheresis-sessions compared with 5 granulocytes and monocytes adsorption apheresis-sessions on clinical remission rate in patients with active ulcerative colitis. 
(B) The effect of intensive granulocytes and monocytes adsorption apheresis compared with weekly granulocytes and monocytes adsorption apheresis on clinical remission rate in patients with active ulcerative colitis.

GMAA; granulocytes and monocytes adsorption apheresis

M-H; Mantel-Haenszel

CI; confidence interval

Figure 5: The adverse events rate of granulocytes and monocytes adsorption apheresis compared with corticosteroids in patients with active ulcerative colitis.

GMAA; granulocytes and monocytes adsorption apheresis

M-H; Mantel-Haenszel

CI; confidence interval 
Figure 1: Literature screening and selection process.

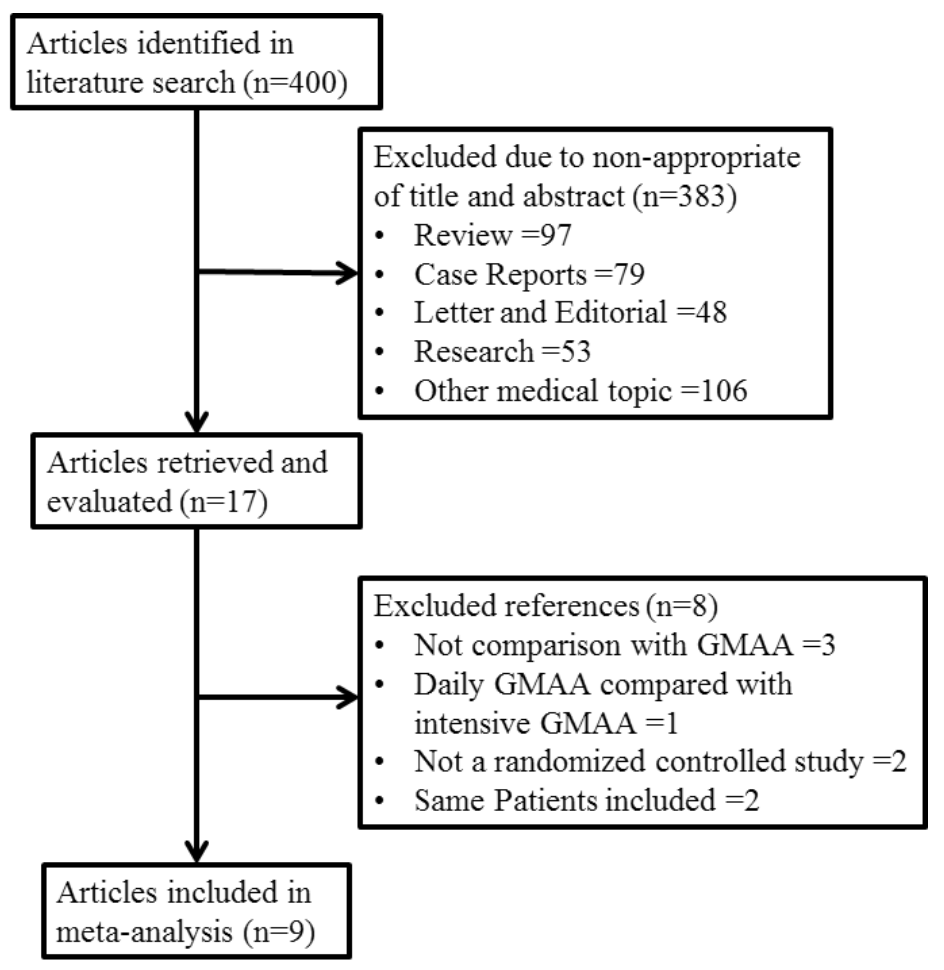

The search strategy identified a total of 400 citations. 383 of 400 citations were excluded and the remaining seventeen were retrieved and evaluated in more detail. Of 17 studies, 9 were included in this meta-analysis. 
Figure 2: The effect of GMA compared with corticosteroids on rate of clinical remission and response in patients with active UC

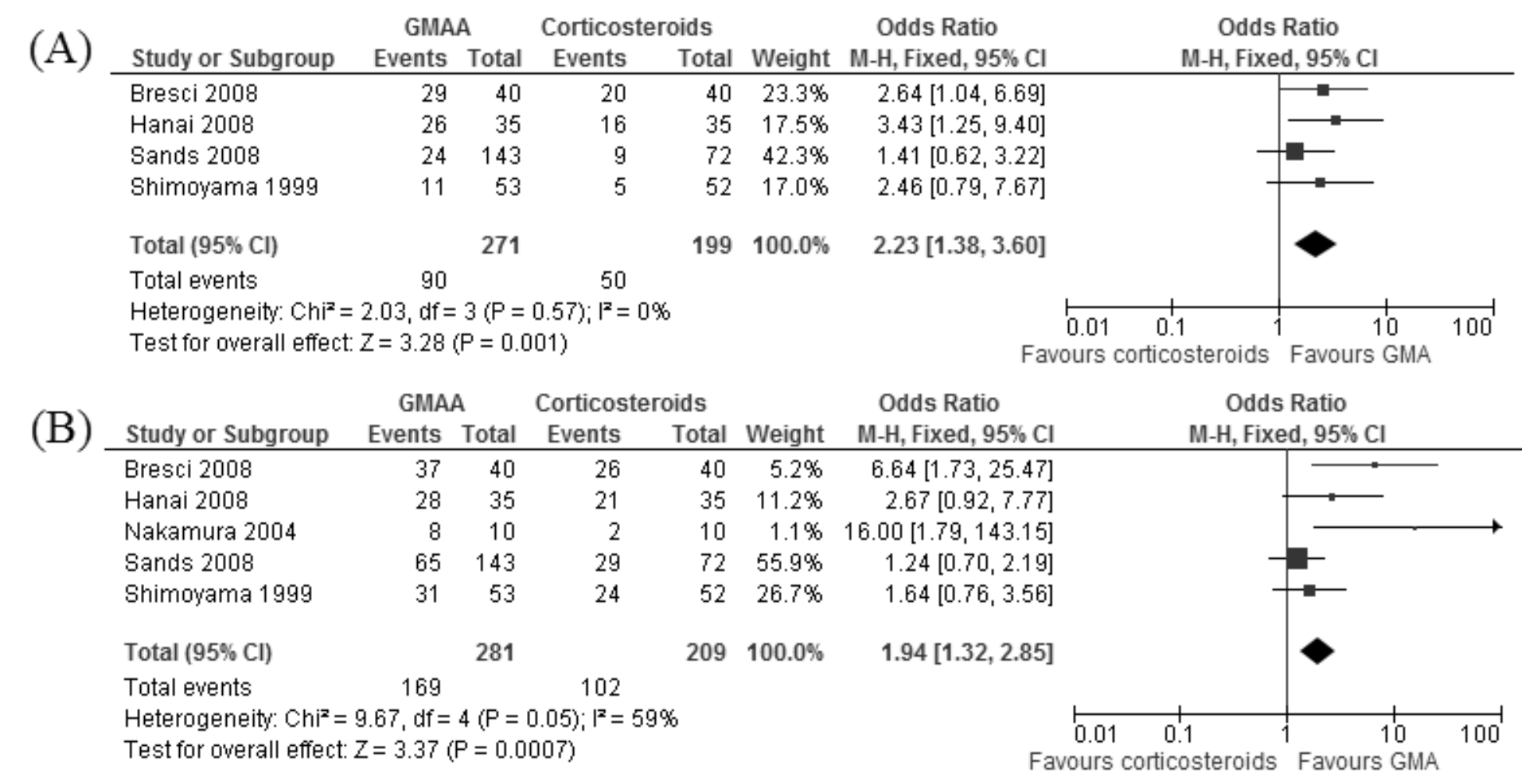

(A) The effect of GMAA compared with corticosteroids on clinical remission rate in patients with active UC.

(B) The effect of GMAA compared with corticosteroids on clinical response rate in patients with active UC.

GMAA; granulocytes and monocytes adsorption apheresis

\section{M-H; Mantel-Haenszel}

CI; confidence interval 
Figure 3: The effect of GMAA compared with corticosteroids on clinical remission rate in patients with severe and moderate UC.

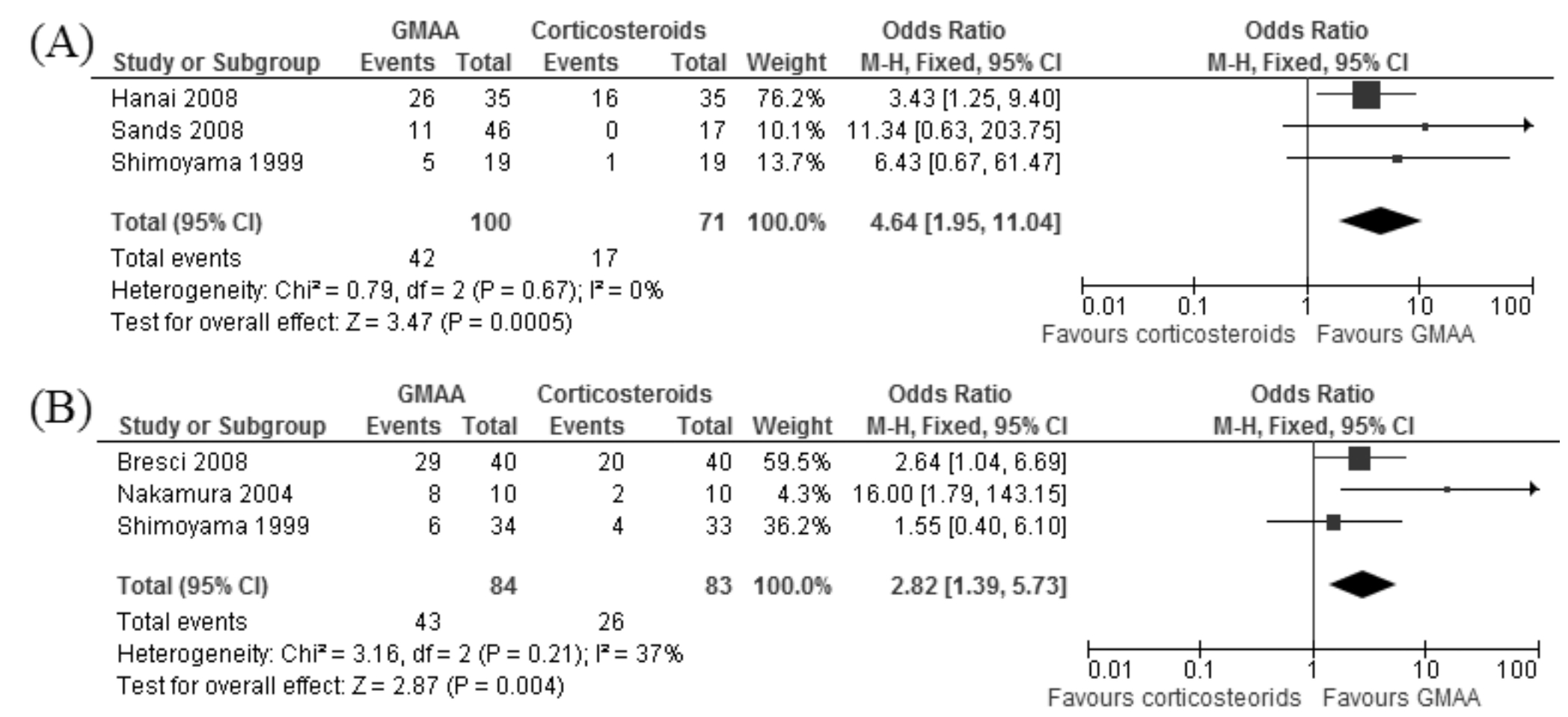

(A) The effect of GMAA compared with corticosteroids on clinical remission rate in patients with severe UC.

(B) The effect of GMAA compared with corticosteroids on clinical remission rate in patients with moderate UC.

GMAA; granulocytes and monocytes adsorption apheresis

\section{M-H; Mantel-Haenszel}

CI; confidence interval 
Figure 4: The evaluation of therapeutic effect of GMAA on clinical remission rate in patients with active UC by comparing GMAA regimens.

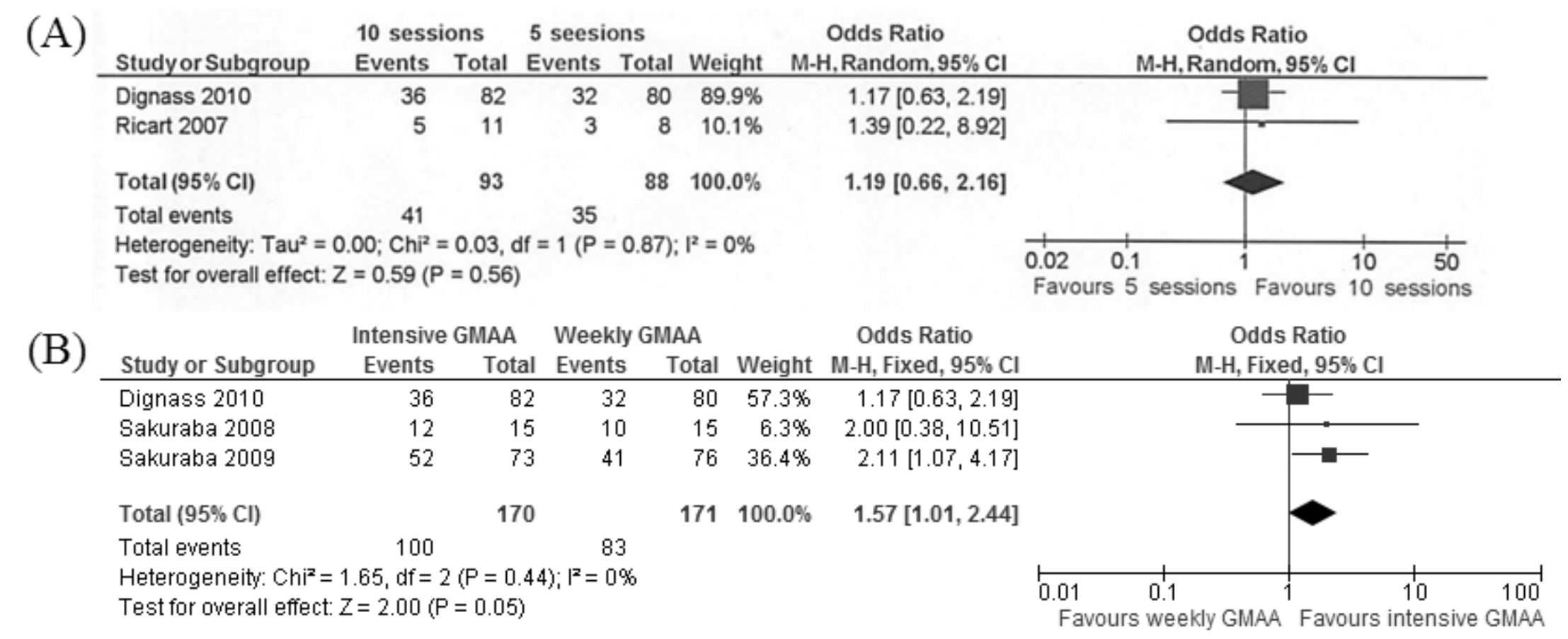

(A) The effect of 10 GMAA-sessions compared with 5 GMAA-sessions on clinical remission rate in patients with active UC.

(B) The effect of intensive GMAA compared with weekly GMAA on clinical remission rate in patients with active UC.

GMAA; granulocytes and monocytes adsorption apheresis

M-H; Mantel-Haenszel

CI; confidence interval 
Figure 5: The adverse events rate of GMAA compared with corticosteroids in patients with active UC.

\begin{tabular}{|c|c|c|c|c|c|c|c|c|}
\hline \multirow[b]{2}{*}{ Study or Subgroup } & \multicolumn{2}{|c|}{ GMAA } & \multicolumn{2}{|c|}{ Corticosteroids } & \multirow[b]{2}{*}{ Weight } & \multirow{2}{*}{$\begin{array}{c}\text { Odds Ratio } \\
\text { M-H, Fixed, } 95 \% \mathrm{Cl}\end{array}$} & \multirow{2}{*}{\multicolumn{2}{|c|}{$\begin{array}{c}\text { Odds Ratio } \\
\text { M-H, Fixed, } 95 \% \mathrm{Cl}\end{array}$}} \\
\hline & Events & Total & Events & Total & & & & \\
\hline Bresci 2008 & 4 & 40 & 20 & 40 & $24.8 \%$ & $0.11[0.03,0.37]$ & $\longrightarrow$ & \\
\hline Hanai 2008 & 5 & 35 & 29 & 35 & $34.3 \%$ & $0.03[0.01,0.13]$ & $\longleftrightarrow$ & \\
\hline Sands 2008 & 131 & 143 & 64 & 72 & $9.8 \%$ & $1.36[0.53,3.50]$ & & \\
\hline Shimoyama 1999 & 5 & 59 & 24 & 56 & $31.1 \%$ & $0.12[0.04,0.36]$ & & \\
\hline Total $(95 \% \mathrm{Cl})$ & & 277 & & 203 & $100.0 \%$ & $0.21[0.13,0.35]$ & & \\
\hline Total events & 145 & & 137 & & & & & \\
\hline $\begin{array}{l}\text { Heterogeneity: } \mathrm{Chi}^{2}= \\
\text { Test for overall effect }\end{array}$ & $\begin{array}{l}24.67, \mathrm{df} \\
Z=5.91\end{array}$ & $\begin{array}{l}=3(\mathrm{P} \\
\mathrm{P}<0.0\end{array}$ & $\begin{array}{l}0.0001) ; \\
0001)\end{array}$ & $=88 \%$ & & & $\begin{array}{lc}0.01 & 0.1 \\
\text { vours corticoster }\end{array}$ & Favours GMAA \\
\hline
\end{tabular}

GMAA; granulocytes and monocytes adsorption apheresis

M-H; Mantel-Haenszel

CI; confidence interval 


\section{Table 1: Characteristics of included studies in this meta-analysis}

\begin{tabular}{|c|c|c|c|c|c|c|c|c|c|c|c|c|c|}
\hline Reference & Country & $\begin{array}{c}\text { number of } \\
\text { centers }\end{array}$ & Methodology & $\begin{array}{c}\text { Criteria for } \\
\text { clinical remission }\end{array}$ & $\begin{array}{c}\text { Criteria for } \\
\text { clinical response }\end{array}$ & Participants & Disease severity & $\begin{array}{l}\text { Duration of } \\
\text { follow-up }\end{array}$ & $\begin{array}{c}\text { Active } \\
\text { intervention }\end{array}$ & $\begin{array}{c}\text { Control } \\
\text { intervention }\end{array}$ & $\begin{array}{l}\text { Number of } \\
\text { responder with } \\
\text { active intervention }\end{array}$ & $\begin{array}{c}\text { Number of } \\
\text { responder with } \\
\text { control intervention }\end{array}$ & $P$-value \\
\hline $\begin{array}{l}\text { Shimoyama et al. } \\
1999[22]\end{array}$ & Japan & 14 sites & $\begin{array}{l}\text { Randomization } \\
\text { and unblinded }\end{array}$ & $\begin{array}{l}\text { Original clinical } \\
\text { activity score }\end{array}$ & $\begin{array}{l}\text { Original clinical } \\
\text { activity score }\end{array}$ & 120 patients & $\begin{array}{c}\text { moderate }(n=74(61.7 \%)) \\
\text { severe }(n=46(38.3 \%))\end{array}$ & 7 weeks & $\begin{array}{l}5 \text { weekly- } \\
\text { apheresis }\end{array}$ & $\begin{array}{l}\text { treatment with } \\
\text { corticosteroids }\end{array}$ & $\begin{array}{c}\text { Remission:11/53 } \\
(\mathbf{2 0 . 8 \% )} \\
\text { Response:31/53 } \\
(58.5 \%)\end{array}$ & $\begin{array}{c}\text { Remission:7/52 } \\
(13.5 \%) \\
\text { Response:24/52 } \\
(46.2 \%)\end{array}$ & $\begin{array}{l}0.464 \\
0.206\end{array}$ \\
\hline $\begin{array}{l}\text { Nakamura et al. } \\
2004[25]\end{array}$ & Japan & 3 sites & $\begin{array}{l}\text { Randomization } \\
\text { and blinding } \\
\text { unclear }\end{array}$ & $\begin{array}{l}\text { Original clinical } \\
\text { activity score }\end{array}$ & $\begin{array}{l}\text { Original clinical } \\
\text { activity score }\end{array}$ & 20 patients & moderate & 6 weeks & $\begin{array}{l}5 \text { weekly- } \\
\text { apheresis }\end{array}$ & $\begin{array}{l}\text { treatment with } \\
\text { corticosteroids }\end{array}$ & $\begin{array}{l}\text { Response:8/10 } \\
\quad(80 \%)\end{array}$ & $\begin{array}{c}\text { Response:2/10 } \\
(20 \%)\end{array}$ & $<0.05$ \\
\hline $\begin{array}{l}\text { Bresci et al. } \\
2008[26]\end{array}$ & Italy & 1 site & $\begin{array}{l}\text { Randomization } \\
\text { and blinding } \\
\text { unclear }\end{array}$ & $\begin{array}{c}\text { CAI score }<6 \\
\text { and endoscopic } \\
\text { score }<4\end{array}$ & $\begin{array}{c}\text { CAI score }<6 \\
\text { and endoscopic } \\
\text { score }<4\end{array}$ & 80 patients & $\begin{array}{c}\text { mild-moderate } \\
\text { (mean CAI score: } 8.5 \pm 2 \text { ) }\end{array}$ & 6 weeks & $\begin{array}{l}5 \text { weekly- } \\
\text { apheresis }\end{array}$ & $\begin{array}{l}\text { methylprednoslone } \\
0.8-1.0 \mathrm{mg} / \mathrm{kg} / \mathrm{day} \text { for } 2 \\
\text { weeks }\end{array}$ & $\begin{array}{c}\text { Remission:29/40 } \\
(72.5 \%) \\
\text { Response:37/40 } \\
(92.5 \%)\end{array}$ & $\begin{array}{c}\text { Remission:20/40 } \\
(50 \%) \\
\text { Response:26/40 } \\
(65 \%)\end{array}$ & $\begin{array}{l}0.039 \\
<0.05\end{array}$ \\
\hline $\begin{array}{c}\text { Hanai et al. } \\
2008 \text { [24] }\end{array}$ & Japan & 5 sites & $\begin{array}{l}\text { Randomization } \\
\text { and } \\
\text { investigator- } \\
\text { blinded }\end{array}$ & CAI score $\leq 4$ & $\begin{array}{l}\text { CAI score decreased } \\
\text { by } \geq 5 \text { points, but } \\
\text { remained } \geq 5\end{array}$ & 70 patients & $\begin{array}{c}\text { severe } \\
\text { (CAI score range:10-23) }\end{array}$ & 12 weeks & $\begin{array}{l}2 \text { weekly apheresis } \\
\text { for } 3 \text { weeks, then up } \\
\text { to } 5 \text { further sessions }\end{array}$ & $\begin{array}{c}\text { intravenous } \\
\text { prednisolone } \\
(40-60 \mathrm{mg} / \text { day })\end{array}$ & $\begin{array}{c}\text { Remission:26/35 } \\
(74.3 \%) \\
\text { Response:28/35 } \\
(80 \%)\end{array}$ & $\begin{array}{c}\text { Remission: } 16 / 35 \\
(48.6 \%) \\
\text { Response:21/35 } \\
(60 \%)\end{array}$ & $\begin{array}{l}<0.05 \\
0.117\end{array}$ \\
\hline $\begin{array}{l}\text { Sands et al. } 2008 \\
\quad \text { [27] }\end{array}$ & $\begin{array}{c}\text { USA, } \\
\text { Canada, } \\
\text { Europe } \\
\text { and Japan }\end{array}$ & 48 sites & $\begin{array}{l}\text { Randomization } \\
\text { and double- } \\
\text { blinded }\end{array}$ & $\begin{array}{l}\text { Mayo score of } \leq 2 \text {, with } \\
\text { a score of ofor rectal } \\
\text { bleeding and } \leq 1 \text { for } \\
\text { endoscopic activity }\end{array}$ & $\begin{array}{l}\text { Mayo score reduction } \\
\text { of } \geq 3 \text { points from } \\
\text { baselaine }\end{array}$ & 215 patients & $\begin{array}{l}\text { moderate and severe } \\
\text { (Mayo score range: } 6 \text { to 11) }\end{array}$ & 12 weeks & $\begin{array}{l}10 \text { weekly- } \\
\text { apheresis }\end{array}$ & $\begin{array}{l}10 \text { sham weekly- } \\
\text { apheresis }\end{array}$ & $\begin{array}{c}\text { Remission:24/143 } \\
(17 \%) \\
\text { Response:65/143 } \\
(46 \%)\end{array}$ & $\begin{array}{c}\text { Remission:9/72 } \\
(13 \%) \\
\text { Response:29/72 } \\
(40 \%)\end{array}$ & $\begin{array}{l}0.560 \\
0.548\end{array}$ \\
\hline $\begin{array}{l}\text { Ricart et al. } \\
2007[28]\end{array}$ & Spain & 5 sites & $\begin{array}{l}\text { Randomization } \\
\text { and unblinded }\end{array}$ & CAI score $\leq 4$ & none & $\begin{array}{l}20 \text { patients with } \\
\text { corticosteroid- } \\
\text { dependent UC }\end{array}$ & $\begin{array}{c}\text { moderate } \\
\text { (CAI score range:6-12) }\end{array}$ & 17 weeks & $\begin{array}{l}10 \text { weekly- } \\
\text { apheresis }\end{array}$ & $\begin{array}{l}5 \text { apheresis over } \\
5 \text { weeks }\end{array}$ & $\begin{array}{c}\text { Remission:5/11 } \\
(45.5 \%)\end{array}$ & $\begin{array}{c}\text { Remission:3/8 } \\
\text { (37.5\%) }\end{array}$ & N.S. \\
\hline $\begin{array}{l}\text { Dignass et al. } \\
2010[29]\end{array}$ & Europe & 42 sites & $\begin{array}{l}\text { Randomization } \\
\text { and unblinded }\end{array}$ & CAI score $\leq 4$ & $\begin{array}{c}\text { CAI score } \\
\text { decreased by } \\
\geq 3 \text { points }\end{array}$ & $\begin{array}{c}186 \text { patients with } \\
\text { corticosteroid- } \\
\text { dependent or resistant } \\
\text { UC }\end{array}$ & $\begin{array}{c}\text { moderate-severe } \\
\text { (mean CAI score:8.7-8.8) }\end{array}$ & 12 weeks & $\begin{array}{c}2 \text { apheresis/week } \\
\text { over } 2 \text { weeks, then } 6 \\
\text { weekly-apheresis }\end{array}$ & $\begin{array}{l}5 \text { apheresis over } \\
5 \text { weeks }\end{array}$ & $\begin{array}{c}\text { Remission:36/82 } \\
\text { (44\%) }\end{array}$ & $\begin{array}{c}\text { Remission:32/80 } \\
\text { (40\%) }\end{array}$ & N.S. \\
\hline $\begin{array}{l}\text { Sakuraba et al. } \\
2008[30]\end{array}$ & Japan & 1 site & $\begin{array}{l}\text { Randomization } \\
\text { and unblinded }\end{array}$ & CAI score $\leq 4$ & $\begin{array}{l}\text { CAI score decreased } \\
\text { by } \geq 3 \text { points, but } \\
\text { remained }>4\end{array}$ & 30 patients & $\begin{array}{c}\text { moderate } \\
\text { (CAI score range:7-12) }\end{array}$ & $\begin{array}{l}\text { Intervention } \\
\text { (7 weeks) } \\
\text { Control } \\
\text { (11 weeks) }\end{array}$ & $\begin{array}{c}3 \text { apheresis/week } \\
\text { over } 2 \text { weeks, then } 4 \\
\text { weekly-apheresis }\end{array}$ & $\begin{array}{l}10 \text { apheresis over } \\
10 \text { weeks }\end{array}$ & $\begin{array}{c}\text { Remission:12/15 } \\
(80 \%)\end{array}$ & $\begin{array}{c}\text { Remission:10/15 } \\
\text { (67\%) }\end{array}$ & N.S. \\
\hline $\begin{array}{l}\text { Sakuraba et al. } \\
2009 \text { [31] }\end{array}$ & Japan & 24 sites & $\begin{array}{l}\text { Randomization } \\
\text { and unblinded }\end{array}$ & CAI score $\leq 4$ & $\begin{array}{l}\text { CAI score decreased } \\
\text { by } \geq 3 \text { points, but } \\
\text { remained }>4\end{array}$ & 149 patients & $\begin{array}{l}\text { mild-moderate } \\
\text { (CAI score range:5-12) }\end{array}$ & $\begin{array}{l}\text { Intervention } \\
\text { (5 weeks) } \\
\text { Control } \\
\text { (10 weeks) }\end{array}$ & $\begin{array}{l}2 \text { apheresis/week } \\
\text { over } 5 \text { weeks }\end{array}$ & $\begin{array}{l}10 \text { apheresis over } \\
10 \text { weeks }\end{array}$ & $\begin{array}{c}\text { Remission:52/73 } \\
\text { (72\%) }\end{array}$ & $\begin{array}{c}\text { Remission:41/76 } \\
\text { (54\%) }\end{array}$ & 0.03 \\
\hline
\end{tabular}

Original clinical activity score: Original scoring system based on clinical symptoms, endoscopic findings and inflammatory markers. Disappearance of two of three clinical factors (abdominal pain, bloody stool and diarrhea) and endoscopic findings of active UC (erosions, ulcers, mucous and bloody stool and indistinct vascular pattern), and normalization or significantly improvement of C-reactive protein were defined as clinical remission. Improvement of two of 
those three factors, such as clinical factors, endoscopic findings and level of C-reactive protein was defined as clinical response.

CAI score: clinical activity index score 